\title{
Attitudes and Opinions of Community Health Nurses on Nursing Discharge Summaries and Cooperation with Hospital Nurses
}

1 Kristina Hanžek

1 University Hospital Centre Zagreb, Department of Neurology

Article received: 11.06.2017.

Article accepted: 05.10.2017.

Author for correspondence:

Kristina Hanžek, University Hospital Centre Zagreb, Kišpatićeva 12, HR- 10000 Zagreb, Croatia

DOI: $10.24141 / 2 / 1 / 1 / 4$

Keywords: community health nurses, nursing discharge summary

\section{Abstract}

Aim: To examine the attitudes and opinions of community health nurses on nursing discharge summaries (NDS) as a form of cooperation with hospital nurses in terms of improving mutual cooperation.

Methods: A total of 27 community health nurses employed at two health care centres in the City of Zagreb participated in the study. Four focus group discussions were held, led by a moderator and observed by a researcher. The participants were given statements and open-ended questions which allowed them to freely express their personal views, thoughts, opinions and doubts. The data was anaIysed in accordance with the principles of one of the most influential models of qualitative data analysis of the authors Glaser and Strauss.

Results: Four main topics were derived from data analysis: 1) knowledge of NDS; 2) features of existing NDS; 3) elements of cooperation between community health nurses and hospital nurses via existing NDS; 4) recommendations for the improvement of NDS.

Conclusion: Routine issuance of NDS for each patient indicating the continuation of nursing care after being discharged contributes to improved cooperation between nurses at different nursing care levels, emphasizes the role of the nurse in cost-effective planning and nursing care and, most importantly, ensures cost-effective, continuous, holistic and quality nursing care for each individual patient. 


\section{Introduction}

According to the Nursing Act, one of the duties of a nurse is to keep nursing documentation that will record all procedures performed during 24 hours (1).

The purpose of keeping nursing documentation is manifold. It is a source of information on the basis of which it is possible to acquire results useful for the development of nursing practice through study. Furthermore, it ensures legal protection - a document that verifies facts and assertions in the case of a dispute or disagreement; it enables the tracking of expenses according to the efficiency of care and is one of the standards in nursing internationally (2).

The process of nursing documentation implementation in the Republic of Croatia began in 2011 when the Ordinance on nursing documentation in hospitals was issued, determining the contents and the forms for nursing documentation in hospitals. According to the Ordinance, the NDS form is an obligatory part of nursing documentation and is to be written for patients that need a continuation of nursing care after discharge from hospital (3). NDS are an important part of nursing documentation and are meant to improve how community health nurses are informed on continuing care, not just for patients that are being discharged from hospital, but also for the healthy population of community health care users, e.g. pregnant women who need breastfeeding training or patients that need education on health issues.

Despite the aforementioned advantages of working with NDS, the results of current studies indicate the need for improvement of cooperation between hospital and community health nurses using NDS. Bjuresäter and collaborators in the qualitative study of experiences by community health nurses in Sweden determined the need for improving the cooperation and communication between nurses in hospitals and community services (4). Hesselink and collaborators in their study in the Netherlands also confirmed certain shortcomings in the collaboration between hospital and community health nurses through NDS, where community health nurses asserted that important patient discharge information would often be omitted or would be incomplete, unclear or delayed (5).
Previous experiences with NDS in our country indicate that this way of communication and cooperation between nurses at the primary, secondary and tertiary health protection levels is still inadequately developed and is still, despite recommendations, not the usual way of their cooperation. Since no relevant literature exists so far and studies in this area are rare in the Republic of Croatia, this qualitative study was carried out to examine the attitudes and opinions of community health nurses about the existing nursing discharge summaries and their suggestions for their improvement.

\section{Methods}

After obtaining the permission for the study from the ethics commissions of the Zagreb-Centar and Zagreb-Zapad health care centres, head nurses of these institutions were contacted by telephone with the request to recruit community health nurses for the focus groups.

The letter of invitation that contained information on the study was sent to a total of 29 community health nurses, with 27 accepting the invitation (response rate $93.1 \%$ ). Community health nurses willing to take part in the study were divided into 4 focus groups, with 6 community health nurses in the first and third focus group, 7 in the second focus group and 8 community health nurses in the fourth focus group. The selection criterion for the focus group participants was that the community health nurses willing to take part in the study had experience with NDS in their previous work. Every focus group met only once, with group discussions lasting between 90 and 120 minutes.

Among the 27 community health nurses that responded, all were female, aged from 23 to 64. Length of service was under 10 years in case of 16 of 27 community health nurses, whereas 11 had worked longer than 10 years. Of the 27 participating community health nurses, 4 held a master's degree, while others held bachelor's degrees. 


\section{Focus groups}

All four focus group discussions were managed by the same moderator and were observed by a researcher. The moderator was a university educated woman with a background in medicine and experience in moderating focus groups. The participants were notified that the purpose of the focus group was to encourage interaction between participants and that they were completely free to express their personal views, thoughts, opinions and concerns within the scope of the topic. Focus group sessions were held separately in the premises of the ZagrebCentar and Zagreb-Zapad health care centres over a period of three months.

\section{Data analysis}

Focus group discussions were recorded using a voice recorder, and a transcript was written subsequently. The data was analysed through qualitative analysis based on the principles of the grounded theory of Glaser and Strauss - one of the most influential models in qualitative data analysis. The basic premise of the grounded theory is to draw key topics from the gathered data, and not to place the data in pre-established categories. Thus, one starts from an individual case, an incident or occurrence, and then gradually develops and synthesizes abstract conceptual categories, trying to interpret the data and identify patterns of behaviour among them. The final theory includes a set of developed concepts, connected by defined relations that together form a framework for the description or prediction of phenomena.

For the purpose of correct and complete text content (and context) understanding, a meticulous data analysis was performed word by word and line by line aimed at achieving credibility and avoidance of researcher bias or data criticism (7). Three main coding procedures were performed: open, axial and selective coding. Among these three types of procedures, no clear demarcation line had been set, but they were continuously combined. Through final analysis, these analytical procedures were set in a reference frame of the conditional matrix.

Data analysis was performed by two researchers after every focus group session, first independently, then in agreement with each other, according to the codes, categories, concepts and resulting theories. The analysis included the observer's feedback, since he was present at every discussion, listening and watching attentively.

\section{Results}

Through qualitative analysis of the data gathered by the focus group method, four main topics and explanatory models were derived: 1 ) knowledge of NDS; 2 ) features of existing NDS; 3) elements of cooperation between community health nurses and hospital nurses via existing NDS; 4) recommendations for the improvement of NDS.

\section{Topic 1) Knowledge of NDS}

Although the majority of community health nurses had experience with NDS in their work, these NDS were written mostly for patients with diabetes, chronic wounds, as well as pregnant women and newborn babies. NDS in question were mostly written at patients' discharge from hospital (Clinical hospital "Sveti Duh", Clinical hospital "Sestre Milosrdnice", Clinical hospital "Merkur", as well as for chronic patients from the Special Hospital for Pulmonary Diseases). Although NDS are not a standard working procedure in these health care institutions, all community health nurses agreed that NDS were necessary and cited their positive role in ensuring nursing care for patients after their discharge from hospital, either ensuring easier planning for nursing care procedures or continuity of nursing care.

Quotes from community health nurses:

"We either don't get them, or they are inadequate, sometimes the data is incorrect, or worst of all we don't get them..." (Community health nurse 8, FG 2).

"I also had to deal with these discharge summaries from Vuk Vrhovac clinic, but that is a project, not routine practice that... it's about diabetics."

(Community health nurse 12, FG 2).

\section{Topic 2) Features of existing NDS}

Most community health nurses participating in the study pointed out the non-uniformity of received NDS when it comes to forms, appropriateness of content, legibility or correctness of data. Some NDS were written electronically, had adequate content that enabled further nursing care planning and were legible. They contained detailed nursing diagnoses, a description of nursing care procedures performed in 
hospital and recommendations for continuing nursing care for every patient. In contrast to the above, some NDS mostly contained content that was inadequate for further nursing care planning. Furthermore, NDS were partly handwritten (illegible), incomplete and part of the data was incorrect. For example, some postnatal NDS written for mothers who had recently given birth (puerpera) and newborns claimed that the mother was breastfeeding, but at the mother's home it was determined that the breastfeeding process had not been established during hospital stay. Also, in some NDS the presence of pressure ulcers in patients was not recorded, although the patients were discharged with dressings on the wounds.

And finally, the experiences of community health nurses point to the fact that the NDS form is not uniform according to the recommendations of the Croatian Nursing Council (HKMS), but that every ward had adapted the NDS form to its work practice and the needs of their patients' nursing care. However, community health nurses pointed out that certain elements of the form were essential for organising and planning of nursing care - not the forms' layout. The form should specify the nursing care provided in hospital, patient's response to the care, when a wound dressing was changed, when a urinary catheter was changed, etc. Therefore, the layout of the form itself, according to the opinions of community health nurses in focus group discussions, is not essential for nursing care planning. What is essential are its contents.

Quotes from community health nurses:

"My only objection is that the handwritten parts that were photocopied are illegible." (Community health nurse 12, FG 2)

"... our experiences are ... different ... in most cases there is no pressure ulcer description ... nor does it mention how it was treated, when it developed, how old the wound is, was the patient admitted to the hospital with a pressure ulcer, did it develop in hospital, which factors contributed to its development, etc."

(Community health nurse 5, FG 1).

\section{Topic 3) Elements of cooperation between community health nurses and hospital nurses via existing NDS}

\section{Positive elements of cooperation}

All community health nurses have unequivocally pointed out the positive role of NDS in planning and organising nursing care. The following data acquired through NDS was especially emphasized as being useful in the further organising and planning of nursing care: general personal data of the patient (place of residence, phone number, family characteristics, functional and social status), nursing care/ procedures provided in hospital, the patient's current health status, current nursing diagnosis at discharge from hospital, as well as recommendations for the continuation of nursing care and materials needed for nursing care for every patient.

The importance of timely data acquisition through NDS was pointed out several times as being an important factor in time management. The usefulness of sending an e-mail to the head nurse of the health care centre was emphasized, with the head nurse then forwarding the e-mail to the community health nurses according to the patient's place of residence.

According to the statements of community health nurses, the issuance of NDS improves the quality of nursing care from the aspect of the patient because it decreases the possibility of a longer break in nursing care after hospital discharge (i.e. the patient waits less for the continuation of nursing care), which, along with improved information transfer to the community health nurse via NDS (information about the patient and the performed/planned nursing care procedures) contributes to greater patient satisfaction and lessens the care recipient's feeling of being lost in the health care system.

Routine issuance of NDS for every patient that is in need of further nursing care after discharge definiteIy contributes to the professionalization of nursing by emphasizing the importance and indisputability of the place and role of the nurse in cost-effective planning and organising and consequentially ensures a cost-effective, continuous, holistic and good quality nursing care for every patient. 


\section{Negative elements of cooperation}

The fact that the issuance of NDS at discharge of patients requiring further nursing care is still not done routinely negatively affects its implementation. In situations like these, it will surely take the community health nurse a longer time to gather information about the patient's state and nursing care procedures performed in hospital, as well as to plan and organise nursing care. In some cases, even the cost of care increases (e.g. choosing the dressing for a wound).

In some of the received NDS, it was noticed that data was inadequate - either incomplete, incorrect or not up-to-date. For example, a chronic wound a patient already had at discharge from hospital was not registered, or in another instance it was stated a mother was breastfeeding when in fact the breastfeeding procedure was not established. Sometimes the patient's personal data was incorrect. Some NDS never reach the end user - the community health nurse - or they arrive too late, when nursing care has already been organized. Reasons for that include late issuance of NDS by the hospital, keeping NDS in the patient's medical records by the family doctor or misplacement of NDS by the patient.

Quotes from community health nurses:

"My experiences are positive... I got exactly twenty NDS for a patient... Yes, before my first visit, I actually saw everything, the complete picture and that is what I really found in the field." (Community health nurse 7, FG 2).

"Discharge summaries arrive, discharge summaries are being sent, but they get lost on the way. I have here an extensive discharge summary from 2014, issued by the University Clinical Centre Zagreb, and it surely isn't an isolated case, colleagues write summaries for every patient, but what happens later...?"

(Community health nurse 20, FG 4).

\section{Topic 4) Recommendations for the improvement of NDS}

All community health nurses pointed out the benefits of using NDS and stated that such a summary should be sent for every patient who needs further nursing care. In such cases, it would show good nursing practice.

Since different forms of NDS are being used, nurses stated it would be beneficial to create a form that would contain the following elements: personal data and social status of the patient, nursing anamnesis, description of performed nursing procedures, diagnosis according to ICD ( $10^{\text {th }}$ revision) and recommended pharmacotherapy, performed nursing care procedures, current nursing diagnosis after discharge and recommended nursing care after discharge.

Regarding the observed obstacles to the availability of NDS to community health nurses, the need for an increase in its availability was established. It would be useful to point out to the patient and to indicate in the NDS header that the document was intended for the community health nurse ("att. community health nurse"). Furthermore, to make distribution of NDS quicker, community health nurses would prefer that they be sent by e-mail to the head nurse of the health care centre, who would then forward them to community health nurses in the field, according to the patient's place of residence.

"... It should always state... 'Please hand over to the community health nurse or the community health care service' ... in bigger letters so that the doctor also ... when he sees it, hands it over to us... or 'Please deliver to the community health nurse or something like that, until it becomes standard practice."

(Community health nurse 5, FG 1).

\section{Discussion}

The results of this study suggest inadequate cooperation of hospital and community health nurses through NDS, which confirms the hypothesis of this study. Taking into account that NDS are an obligatory part of nursing documentation and that in the Republic of Croatia there is a legal obligation to write nursing documentation, as stated before, its importance is indisputable. Since according to this study NDS are not a routine part of nursing practice in Croatia in most cases, but are instead issued only for a certain category of patients and not for all patients who need continuation of health care, and furthermore that they are issued only by some health care institutions, one should question whether nurses are 
sufficiently acquainted with the legal framework for nursing documentation in the Republic of Croatia. In her research on the introduction of nursing documentation into the IT health care system and its influence on the quality of nursing care, the author Ljubičić also determined that a high percentage (43\% of a total of 217 study participants) of nurses was not informed about the legal framework regulating nursing documentation in the Republic of Croatia (8).

Since nursing documentation in the Republic of Croatia has only partially been implemented electronicalIy on all levels of health care, there are cases where NDS are handwritten, illegible or partially incorrect. NDS written electronically have the advantage of better legibility and accessibility (and can be sent by e-mail), and as such enable simpler archiving with the rest of the patient's documentation after discharge from hospital. Kergoat and collaborators also point out the mentioned benefits of informatisation in health care (9). According to this study, some of NDS were written electronically, had content that enabled further planning of nursing care and were detailed and legible. They contained detailed nursing diagnoses, nursing care procedures performed in hospital and recommendations for continuing nursing care for every patient. This points not just to the advantages of writing NDS electronically because of better legibility, but also to the benefits when filling out NDS, in the sense that a single form for the discharge summary exists in the hospital IT system, as recommended by the Croatian Nursing Council (HKMS). This promotes a uniformity of documentation at an institutional level.

This study shows that there are several forms of NDS in use that are adapted to the institutions that issue them, as well as to the needs of patients who need nursing care after discharge from hospital. However, given the inadequate issuance of NDS that are essential for the organisation and planning of nursing care, community health nurses have pointed out that individual parts contained in the form are more important than the layout of the form. They mentioned the importance of the specification of nursing care provided in hospital, the patient's response to it, when a wound dressing was changed, which one was used, etc. Many studies were conducted for the purpose of improving discharge summaries. In their study conducted in Canada, Kergoat and collaborators concluded that discharge summaries should be adapted in order to improve the quality of informa- tion transfer from the hospital to the community, especially in the case of senior patients (9). NDS are an important part of nursing documentation that should contain not only correct and clear information on a patient after discharge from hospital, but should also reach the end user on time. The results of this study show that some NDS do not reach their end users (community health nurses) on time - they arrive when nursing care has already been organized. Other studies also point out the importance of the timely delivery of this document. In his paper on attitudes, behaviour and obstacles for nurses while planning patient discharge, Graham states that the handover of nursing documentation from the hospital is often not done on time so as to enable the further organisation of patient care (10).

Unlike the aforementioned, there is good cooperation between nurses from some institutions in the Republic of Croatia through NDS - i.e. the information reaches the end user (in this case, the community health nurse) on time. A case was mentioned when NDS are sent by e-mail to head nurses of health care centres who forward them to community health nurses according to the patient's place of residence. The importance of timely data acquisition through NDS was pointed out several times as being an important factor in appropriate time management and choosing the most appropriate nursing care procedure after discharge, thus ensuring continuity in the process of providing nursing care to the patient. In their study on reliability, efficiency, accuracy and timeliness of information transfer between the hospital and the community, Wilson and collaborators state that email can ensure timely, safe and efficient communication and transfer of important data (11).

According to the results of this study, inadequacy of data in parts of NDS was noticed regarding accuracy, clarity and completeness. Community health nurses note the example of a mother who had recently given birth and for whom it was specified that she was breastfeeding, though it was subsequently found that the breastfeeding process was not established during the mother's hospital stay. Others quote the example of patients with pressure ulcers and dressed wounds at discharge from hospital that were not specified in NDS. The quoted examples point to the fact that it would be necessary to analyse the aforementioned poor nurse knowledge about the legal framework for nursing documentation regarding data inaccuracy in NDS. Documenting procedures 
from the field of nursing care should not be a side activity for nurses, but an obligation that is fulfilled responsibly and carefully. Other research also notes insufficient transfer of information from the hospital to the community through documentation, citing inadequate, inaccurate, unclear and incomplete data (5, $12,13,14,15)$.

All community health nurses have pointed out the benefits of using NDS in planning and organising nursing care. Benefits of improved communication between hospital and community health nurses through NDS were especially emphasized, e.g. greater availability and insight into patient records, timely data transfer and better quality information access for the community health nurse. Iveta and collaborators also pointed out the indisputability of NDS in communication improvement (16).

Routine issuance of NDS for every patient that is in need of further nursing care after discharge definitely contributes to the professionalization of nursing, by emphasizing the importance and indisputability of the place and role of the nurse in cost-effective planning and organising and consequentially ensures a cost-effective, continuous, holistic and good quality nursing care for every patient. According to Kalauz, some theoreticians find that for a profession it is crucial to have a clearly articulated identity and an understandable, acceptable and socially accepted role. In spite of that, the description of work duties for nurses in the context of health care institutions is often unclear, which does not support the development of nurses' professional identity. Also, management structures are not making the development of nursing identity an integral part of the identity of the institution (17). It is widely recognised that nursing documentation and documenting nursing care is a unique field of work for the nurse. For that reason, NDS should become a standard in nursing practice, become a daily work routine and be accepted as a unique document that only a nurse can issue and thus become recognized in society as the document of a profession - the profession of nursing, because the recognition of the nursing profession is currently of crucial importance in the Republic of Croatia.

\section{Conclusion}

1. In Croatia, it is still not routine to write NDS for every patient requiring further nursing care, and NDS are issued only for certain groups of patients in most cases (diabetics, patients with chronic wounds, new mothers and newborns); it is common in certain wards in certain hospitals as part of separate projects and not a standard working procedure in these institutions.

2. Most community health nurses pointed out that NDS are not uniform regarding the layout of the form, appropriateness of content, legibility and accuracy of data.

3. Positive elements of cooperation between community health nurses with hospital nurses through existing NDS are as follows: timely transfer of information about the patient through NDS (by e-mail), timely information transfer to the community health nurse contributes to patient satisfaction, routine issuance of NDS contributes to the professionalization of the nursing profession.

4. Negative elements of cooperation between community health nurses and hospital nurses through existing NDS are as follows: non-existence of routine issuance of NDS in nursing practice, inadequate data (incorrect, incomplete, outdated).

5. Recommendations for NDS improvement are as follows: appropriate, accurate, up-to-date data and faster NDS distribution by e-mail.

6. A consensus was reached among community health nurses about the need for the existence of NDS. They cite its positive role in ensuring nursing care for patients after they are discharged from hospital, both ensuring easier planning of nursing care procedures and continuity of nursing care. Therefore, NDS should be issued for every patient who requires a continuation of nursing care. In these cases, NDS are an indicator of good nursing practice. 


\section{Limitations}

Some participants (community health nurses) in the focus group were acquainted with each other. Future research should exclude the possibility of participants being acquainted with each other. There is need for this topic to also be studied in other cities in Croatia.

\section{Acknowledgement}

I would like to express my gratitude to dr. sc. Goranka Petriček, MD, PhD, assistant professor at the Chair of Family Medicine, Andrija Štampar School of Public Health, University of Zagreb School of Medicine

\section{References}

1. Narodne novine. Zakon o sestrinstvu. 2003: br.121. Available from: http://narodne-novine.nn.hr/clanci/ sluzbeni/2003_07_121_1710.html Croatian.

2. Ilić B, Čukljek S. Iskustva medicinskih sestara pri vođenju sestrinske dokumentacije. Medicinska informatika 2013; 11: 33-36. Croatian. Available from: https://www.researchgate.net/profile/Boris_llic/ publication/261402787_Iskustva_medicinskih_sestara_pri_vodenju_sestrinske_dokumentacije/ links/0a85e5343161663087000000/Iskustvamedicinskih-sestara-pri-vodenju-sestrinske-dokumentacije.pdf. Retrieved 29.052017.

3. Narodne novine. Pravilnik o sestrinskoj dokumentaciji u bolničkim zdravstvenim ustanovama. 2011: br. 79. Croatian. Available from: http://narodne-novine.nn.hr/ clanci/sluzbeni/2011_07_79_1692.html Retrieved: 20. 042017.

4. Bjuresäter K, Larsson M, Nordström G. Cooperation in the care for patients with home enteral tube feeding throughout the care trajectory: nurses' perspectives. J Clin Nurs. 2008; 17: 3021-29. Available from: https:// www.ncbi.nlm.nih.gov/pubmed/19034990

5. Hesselink G, et al. "Quality and safety of hospital discharge: a study on experiences and perceptions of patients, relatives and care providers. Internati- onal Journal for Quality in Nursing care. 2013; 25 (1): 66-74. https://doi.org/10.1093/intqhc/mzs066 Available from: https://academic.oup.com/intqhc/article/25/1/66/1937909,

6. Strauss A, Corbin J. Basics of qualitative study techniques. Sage publications 1998.

7. Corbin J, Strauss A. Basics of qualitative study: Techniques and procedures for developing grounded theory. London 2nd edition Sage publications 1998.

8. Ljubičić, M. Implementacija sestrinske dokumentacije u informacijski zdravstveni sustav i utjecaj na kvalitetu zdravstvene njege [diplomski rad]. Zdravstveno veleučilište: Zagreb; 2010. Croatian.

9. Kergoat MJ, et al. A discharge summary adapted to the frail elderly to ensure transfer of relevant information from the hospital to community settings: a model. BMC geriatrics. 2010;10: 69. https://doi. org/10.1186/1471-2318-10-69

10. Graham JE. Acute care nurses' attitudes, behaviours and perceived barriers towards discharge risk screening and discharge planning. [dissertation]. 2010. Available from: http://hdl.handle.net/10453/21793

11. Wilson S, Ruscoe W, Chapman M, Miller R. General practitioner-hospital communications: a review of discharge summaries. J Qual Clin Pract. 2001; 21(4):104-8. PMID:11856404, DOI: 10.1046/j.14401762.2001.00430.x

12. Kripalani S, Lefevre F, Phillips CO, Williams MV, Basaviah $\mathrm{P}$, Baker DW. Deficits in communication and information transfer between hospital-based and primary care physicians: implications for patient safety and continuity of care. JAMA. 2007; 297(8):831-41. PMID:17327525, DOI:10.1001/jama.297.8.831

13. Törnvall $E$, Wilhelmsson $S$. Nursing documentation for communicating and evaluating care. J Clin Nurs. 2008;17(16):2116-24. doi: 10.1111/j.13652702.2007.02149.x.

14. Kuusisto A, Asikainen P, Saranto K. Medication Documentation in Nursing Discharge Summaries at Patient Discharge from Special Care to Primary Care. J Nurs Care. 2014;3: 147. http://dx.doi.org/10.4172/21671168.1000147

15. Alper E, O'Malley TA, Greenwald J. Hospital discharge and readmission. Up To Date 2017. Available from: http://www.uptodate.com/contents/hospital-discharge-and-readmission.

16. Iveta V, Krečak A, Kalogjera M, Milić Đ. Uloga sestrinske dokumentacije u analizi rizika za nastanak dekubitusa. Acta Medica Croatica. 2014; 68:21-7. Croatian.

17. Kalauz S. Etika u sestrinstvu. Zagreb: Medicinska naklada; 2012. Croatian. 


\section{STAVOVI I MIŠLJENJA PATRONAŽNIH MEDICINSKIH SESTARA O OTPUSNOM PISMU ZDRAVSTVENE NJEGE I SURADNJI S BOLNIČKIM MEDICINSKIM SESTRAMA}

\section{Sažetak}

Cilj. Istražiti mišljenja i stajališta patronažnih sestara o otpusnom pismu zdravstvene njege (OPZNJ) kao obliku suradnje s bolničkim medicinskim sestrama u svrhu unaprjeđenja njihove suradnje.

Metode. Ukupno je sudjelovalo 27 patronažnih sestara zaposlenih u dva doma zdravlja u gradu Zagrebu. Održane su četiri rasprave u fokusnoj skupini, uz vodstvo moderatora te opservaciju istraživača. Pred sudionike su bile iznesene izjave i pitanja otvorenog tipa, na koja su bili potpuno slobodni izraziti svoje osobne poglede, misli, stajališta i brige. Podaci su analizirani po načelima jednog od najutjecajnijih modela kvalitativne analize podataka, autora Glasera i Straussa.

Rezultati. Iz analize podataka proizašle su četiri glavne teme: 1) poznavanje OPZNJ-a; 2) obilježja postojećeg OPZNJ-a; 3) elementi suradnje patronažnih sestara s bolničkim medicinskim sestrama putem postojećeg OPZNJ-a; 4) preporuke za unaprjeđenje OPZNJ-a.

Zaključak. Rutinsko izdavanje OPZNJ-a za svakog bolesnika u kojeg je indiciran nastavak provođenja zdravstvene njege nakon otpusta pridonosi boljoj suradnji medicinskih sestara na različitim razinama zdravstvene skrbi, ističe ulogu medicinske sestre u racionalnom planiranju i organizaciji skrbi te, što je najvažnije, osigurava racionalnu, neprekinutu, holističku i kvalitetnu zdravstvenu njegu svakoga pojedinog bolesnika.
Ključne riječi: patronažne sestre, otpusno pismo zdravstvene njege 